\title{
ASPECTS OF MARINE SPATIAL PLANNING AND GOVERNANCE: ADAPTING TO THE TRANSBOUNDARY NATURE AND THE SPECIAL CONDITIONS OF THE SEA
}

\author{
MARILENA PAPAGEORGIOU ${ }^{1, *}$ and STELLA KYVELOU ${ }^{2}$ \\ ${ }^{1}$ Department of Planning and Regional Development, University of Thessaly, Volos 38334, Greece \\ 2 Department of Economics and Regional Development, School of Sciences of Economics and Public Administration, Panteion \\ University of Social and Political Sciences, Athens, Greece \\ *Corresponding author: marpapageo@prd.uth.gr
}

\section{ABSTRACT}

Extension of spatial planning from land to the marine space has recently become a key procedure for tackling the growing environmental and blue growth related challenges. However, given the transboundary nature of the sea (facilitating the flow of all kinds of materials and calling for special considerations in terms of resource and ecosystem management) not all the philosophy, planning models and procedures can be "transplanted" from terrestrial to marine spatial planning. Governance issues are subject to the same limitation.

This paper discusses key differences in the marine environment (compared to the land), which affect marine spatial planning and governance and is structured around the following key issues: (i) the public status of the sea, which involves a wide spectrum of stakeholders (among them the maritime regimes), (ii) the sovereign rights in the sea that are not separately defined by each state but by UNCLOS (especially beyond the territorial waters), (iii) the geopolitical constraints on proclaiming EEZs that reduce the area within which each coastal country can practice MSP, (iv) the usually non-defined administrative limits in the marine parts of a coastal country that impede decentralization of competencies and decision making, and ( $v$ ) the lack of geospatial and socio-economic and cultural data, which creates uncertainty both for the planners and decision-makers.

This article concludes by highlighting the need for adopting a tailor-made MSP research agenda and by stressing the need to enhance crossborder cooperation as well as to make transboundary considerations when planning in the sea.

Keywords: marine governance; Marine Spatial Planning (MSP); transboundary MSP

\section{Introduction}

\section{The need for extending spatial planning from land to sea}

Oceans and seas cover more than two thirds (2/3) of planet Earth. However, it was not until recently that marine space has become "home" to a constantly growing number of activities and human uses (Orams 1999). Indeed, improvements in technology make it much easier than ever to both exploit marine resources at great distances and greater depths and construct resilient infrastructure and facilities in seas for the operation of several economic activities (Hall 2001). As a result, the spectrum of human uses taking place in the sea has grown to include, apart from traditional activities (such as navigation and maritime transport, fisheries, etc.), extraction of hydrocarbons and aggregates; energy production; aquaculture; tourism and leisure; research and protection of the marine natural and cultural heritage; military uses and so on (Smith et al. 2011).

However, these new trends in the use of the sea are not always beneficial and without adverse effects. As recent research indicates (e.g. Millennium Ecosystem Assessment 2005), the constant growth of sea uses (both in volume and number), has resulted in serious alterations in marine biodiversity and damage to marine ecosystems, due to their unplanned management and allocation (Smith et al. 2001; Douvere 2008; Maes 2008). In fact, it is documented worldwide that not only scarce marine resources are threatened by exhaustion and degradation, but also the ability of the ecosystem to keep delivering valuable services both to the environment and to humans (Gilliland and Laffoley 2008).

Considering these facts, extending spatial planning from the land to the sea has recently become a high priority globally, including in the European Union. Having full acknowledgment of the threats that the marine ecosystems are facing, more and more international organizations (or even sole countries) are turning their interest towards a relatively new procedure: Marine/Maritime Spatial Planning (M.S.P.), which is "about planning when and where human activities take place at sea - to ensure these are as efficient and sustainable as possible" (European Commission). MSP is constantly gaining ground for being the key procedure to ensure protection and wise management of the oceans and seas, by tackling the growing competition among marine activities (user-user conflicts), and by ensuring the continuous flow of ecosystem services in the fragile coastal and marine space (user-environment conflicts) (Ehler and Douvere 2008). At the same time, beyond being a process for allocating the different marine uses, MSP also has a strong cultural dimension and is a creative social process of building attractive identities for the sea, to create blue growth and jobs.

However, even though spatial planning has a long tradition on land (terrestrial spatial planning - TSP), not all procedures, philosophy and planning styles can be automatically "transplanted" to MSP (Papageorgiou 2017). The transboundary nature of the sea calls for special consideration in terms of governance and planning 
in marine space. This fact has been largely acknowledged and highlighted by many policy documents, among them those from the EU and U.N. (such as the MSP Directive, the Marine Strategy Directive, the Barcelona Convention and Protocol, and so on) (Fernandes et al. 2013). At the same time, the need for adapting to the transboundary nature of the sea is also reflected in the efforts to conform to a more area-based approach (also known as the Ecosystem Approach), instead of thinking on a geopolitical or sectoral basis when planning in the sea (Hammer 2015; Van Tatenhove 2011).

Given the above context, the present paper explores differences and peculiarities of marine space (related to the transboundary nature of the sea) that should be considered in marine governance and spatial planning. To this end, this paper begins with theoretical and conceptual issues related to "marine spatial planning" and "marine governance" and continues with a discussion of the peculiarities of the sea that affect the way that spatial planning and governance should be practiced in marine space. The ultimate scope of the paper is to contribute to the emerging discussion on how to achieve integrated spatial planning and good and wise governance in marine space, taking into consideration existing planning practices from the land and TSP and the transboundary nature of the sea.

\section{Governance and spatial planning in marine environments}

\section{Marine spatial planning and the ecosystem approach}

Terrestrial spatial planning (TSP) is considered to be far more developed than marine spatial planning (MSP). However, the fact that so far there are very few marine spatial plans world-wide does not necessarily mean that planning in marine space has rarely been practiced up to now. On the contrary, planning in the sea has been very common for a long time, all over the world, on a sectorial basis (Beriatos 2013). The oldest planning attempts regard fishery zonings (to support food and alimentation) and navigation networks (for maritime transport) accompanied by port infrastructures and facilities. Later, in the beginning of the 20th century, sectorial planning attempts included mineral extraction (aggregates, hydrocarbons, etc.), whilst most recently, marine planning has been concerned with a range of other economic activities, such as those related to offshore renewable energy sources (wind power, wave power, etc.) to aquaculture and so on (Smith et al. 2011).

Today, however, when sea uses are constantly growing both in volume and in number, planning in marine space is under reconsideration. The sectorial approach that has prevailed in the sea up to now, even if beneficial according to some scholars (Crowder et al. 2006; Maes 2008; Foley et al. 2010), is being challenged by a more area-based planning approach: the Ecosystem Approach $(\text { EcAp })^{1}$ (Kyvelou 2017). The Ecosystem Approach has been widely adopted by most U.N. and EU documents related to the marine environment (such as the ICZM Protocol, the MSP Directive 2014/89, etc.). According to this area-based approach, spatial planning in marine space should no longer be practiced per sector or per economic activity. Instead, it should be practiced within ecosystem boundaries (marine regions), so that a wiser management of all uses (marine or coastal) and of the environment can be achieved (Douvere 2008; Beriatos 2013; Papageorgiou 2016).

The fact that the ecosystem (or area-based) approach to marine spatial planning is currently receiving more and more attention is due not only to recent environmental concerns but also to the dynamic and transboundary nature of the sea that crosses administrative and national boundaries. This calls for planning initiatives on a wider regional or sea basin scale (Gilliland and Laffoley 2008). However, even if the area-based approach is rather common when planning on land (TSP), not all experiences, philosophy, procedures and planning models and styles can be applied when planning in marine space. Furthermore, pathologies of the TSP, especially in countries that suffer from a series of spatial planning and governance deficiencies, should never be transposed to the MSP process (Kidd 2012; Kyvelou 2016). In fact, a thorough analysis of current attitudes, trends and lessons learnt from MSP world-wide (Kyvelou and Pothitaki 2017) can lead to the suggestion of a tailor-made MSP research agenda for different types of countries and sea-basins that can be linked with the specific evolution of national terrestrial planning systems and the need to investigate further the modes of integration of MSP within national planning systems. This was, in fact, a demand of the Territorial Agenda 2020 of the $\mathrm{EU}^{2}$ on the basis of the land-sea interaction (LSI) principle.

\section{Marine governance}

The term "governance" is of Greek origin: "kyvernan". Governance is a special term that can be defined in different ways (Lalenis 1993; Rhodes 2000), from country to country (Kohler-Koch 1999) or even within each country (Loughlin 2007). According to the U.N. Development Program, governance is defined as "the rules of the po-

1 The Ecosystem Approach is a rather well-known concept among marine biologists since the 1980s and is defined as "the comprehensive integrated management of human activities based on the best available scientific knowledge about the ecosystem and its dynamics, in order to identify and take action on influences which are critical to the health of marine ecosystems, thereby achieving sustainable use of goods and services and maintenance of ecosystem integrity" (ICES, 2003).

2 The EU Territorial Agenda clearly states: "Maritime activities are essential for the territorial cohesion in Europe ... The Marine Strategy Framework Directive and the EU Integrated Maritime Policy call for coordinated actions by the Member States for the successful implementation of the MSP. This planning should be integrated into the existing national spatial planning systems in order to achieve a harmonious and sustainable development of the regions that include both marine and land areas (land-sea continuum)". 
litical system to solve conflicts between actors and adopt decisions (legality)" and also as the "proper functioning of institutions and their acceptance by the public (legitimacy)".

Regarding territorial governance, the CEMAT (Conférence du Conseil de l'Europe des Ministres responsables de l'aménagement du territoire) defines it as "a global concept which characterizes the way spatially-relevant policies, considered together, are applied". According to the same institution (CEMAT), territorial governance is described as "the result of multi-level and cross-sectoral relationships in the field of public policies", also referring to "horizontal and vertical cooperation in the shaping and implementation of these policies". Faludi (2012) notices that in some circles the term territorial governance has lately become synonymous with spatial planning. Nevertheless, territorial governance is responsible for drawing borders, defining the autonomy and the way that territories are governed, defining patterns of co-operation and collaboration, both between governmental and non-governmental actors and between levels of government (Lidström 2007). At the same time, as stressed in the Handbook of CEMAT-YPEN, "for territorial democracy and planning participation in spatial planning" (announced in 2014 during the Greek Presidency), territorial governance is directly connected with "public participation". On the other hand, spatial planning is about allocating functions and infrastructure, identifying urban and economic poles and networks, setting the grounds for economic, social and environmental development and promoting territorial cohesion.

Considering the above, "marine governance" does not differ from "territorial governance", since it has the same objectives and purpose: trying to involve all competent authorities and stakeholders in maritime spatial planning procedures, in a meaningful way (Kraan et al. 2014). According to Van Tatenhove (2011), marine governance is defined as "the sharing of policy making competencies in a system of negotiation between nested governmental institutions at several levels (international, supra national, sub-national) on the one hand and state actors, market parties and civil society organizations of different maritime activities on the other in order to govern activities at sea and their consequences".

Good and wise governance is equally as important to MSP as it is to TSP. However, as in the case of marine spatial planning (MSP), exercise of marine governance should adapt to the transboundary nature of the sea, i.e. take place at a marine regional level rather than considering the geopolitical boundaries, thus limiting governance procedures solely within each coastal state (Hammer 2015; Van Tatenhove 2011). This means that if wise marine governance is to be achieved, it is important to enhance transboundary cooperation at an institutional level, among competent authorities from all the coastal countries sharing the same sea. At the same time, it is also important to ensure meaningful involvement of all stakeholders related to the sea, including maritime regimes (Kraan et al. 2014).

Van Tatenhove has further developed this issue and argues that TMSP (transboundary MSP) should be developed as a reflexive governance arrangement, in which actors would be able to challenge dominant (nationalistic) discourses of MSP, in order to change the institutional rules of the game and develop new institutional rule systems (Van Tatenhove 2017). He suggests three main conditions to achieve this: rule-altering politics, knowledge production and sharing of information, and development of the so-called bordering capabilities versus traditional borders (Sassen 2009), that would change the institutional rules and challenge the discursive space of national marine planning discourses.

This is a ground breaking proposition that certainly fits in with globalisation trends and with the evolving shift of interest towards the partimonialization of the sea versus its jurisdictional dimension (Kyvelou 2016) and the necessity of introducing global marine governance arrangements, at least at the macro-regional level and level of sea-basins.

\section{Peculiarities of the sea to be considered in marine governance and planning}

\section{The transboundary nature of the sea}

The sea is space of a particular nature, compared to the land (Coccossis and Beriatos 2016). It constitutes a fluid mass that facilitates the unimpeded flow of materials, including substances, fish, waste and so on. And despite the fact that it forms a "blue continuum" (one sees nothing but a water surface), the sea constitutes a multidimensional space, including the sea bed, the water column and the surface of the sea (Papageorgiou 2016).

The fact that in the sea no physical boundaries exist, and marine ecosystems and resources transcend administrative and national boundaries, calls for special consideration in terms of marine governance and spatial planning. First of all, resource management has to be considered on a transboundary basis, in order to avoid conflicts among neighbouring countries, and therefore, to ensure viability of marine economic activities for all sides. Second, ecosystem management has to be also considered on a transboundary basis, in order to avoid exceeding the carrying capacity (of shared or adjoining ecosystems) and to avoid marine habitat fragmentation of transnational marine ecosystems (Jay et al. 2016).

Adapting to the transboundary nature of the sea is of prime importance when implementing MSP. However, transboundary MSP considerations and initiatives may face two kinds of challenges (Flannery et al. 2015; Van Tatenhove 2017): institutional and conceptual. Institutional challenges come as a result of the fragmented responsibilities and the different kinds of authorities, institutions, 
policies and regulations existing in a marine region that is surrounded by multiple countries or administrations (Raakjaer et al. 2014; Jay et al. 2016). In fact, such institutional plurality may result in contradictions in decision making, overlapping of competences, as well as misfortunes in governance, causing delays and negatively affecting the efficiency of MSP (Fernandes et al. 2013; Jay et al. 2016; Van Tatenhove 2017).

Conceptual challenges, on the other hand, may come as a result of different approaches among countries sharing the same sea region, regarding the planning and management of their marine space (Van Tatenhove 2017). For example, some countries conceptualize planning and management of their marine parts using the ICM (Integrated Coastal Management) approach, whilst other countries prefer to separate marine planning from that of the land and stick solely to the sea. In other cases, conceptual challenges derive from the fact that some countries are quite advanced in MSP implementation, whilst others are in an experimental phase concerning MSP practices (Flanerry et al. 2015). Differences in the planning approach and the marine planning experience, as well as incompatibilities in the Plans and the planning and management objectives of shared marine regions, may result in serious difficulties in practicing MSP, especially in cases where the distance between neighbouring coastal countries is very close.

Given the above, it becomes evident that the transboundary nature of the sea should always be considered in every planning implementation applied to marine space, and especially in shared marine regions. At the same time, cross-border cooperation as well as transboundary considerations should be a sine qua non, if effective marine spatial planning is to take place. This is particularly necessary, due to the growing political interest in transboundary maritime spatial planning, mostly based on Art. 11 of the MSP Directive that explicitly refers to the need for cooperation between Member States bordering on marine waters. The aim is to ensure that maritime spatial plans are coherent and coordinated across the marine region concerned, indicating that such cooperation shall be pursued using the existing regional institutional cooperation structures (e.g. Regional Sea Conventions); networks/structures of Member States' competent authorities; and/or any other method (e.g. sea-basin strategies).

\section{Jurisdictions and other legal aspects}

The sea significantly differs from the land in terms of jurisdictions and sovereign rights. Up to the territorial waters (T.W.), absolute jurisdiction falls under the coastal states. Beyond T.W., marine space is regulated almost exclusively by the International Law of the Sea (UNCLOS). This means that beyond a certain point, jurisdictions and rights are not only a matter of each coastal state, but also the concern of the international community, resulting in a series of limitations.
According to UNCLOS, territorial waters of coastal countries (i.e. the marine space within which each coastal state has absolute jurisdictions) can extend up to 12 n.m. Beyond territorial waters, each coastal state has the right to proclaim extra zones, the most common of which are the Continental Shelf (C.S.) and the Exclusive Economic Zone (EZZ). However, even in the case that such zones are proclaimed, jurisdictions and rights are not the same as in T.W. As presented in Table 1, coastal countries have less rights within C.S. or EEZ compared to those within T.W. Sovereign rights within the C.S. refer only to the seabed and subsoil of the submarine areas that extend beyond the territorial seas of a country, whilst sovereign rights within the EEZ of a coastal country regarding exploitation, conservation and management of the natural resources (living or non-living), of the waters superjacent to the seabed and of the seabed and its subsoil.

However, even though UNCLOS gives the right to proclaim extra zones, this has not been achieved by many coastal countries. Existing geopolitical conflicts among States sharing the same marine regions may result in extreme difficulties in the proclamation of extra zones beyond the territorial waters, thus hampering the ability of coastal countries to benefit from their surrounding seas.

Considering the above, if effective Marine Spatial Planning is to be achieved, it is essential that coastal countries proclaim their outer marine national limits (and more preferably their EZZ), in order to enlarge the area within which they can implement MSP, and therefore take full advantage of the marine resources, economic opportunities and ecosystem services that their surrounding seas can offer them.

Table 1 Jurisdictions and rights in marine space.

\begin{tabular}{|l|l|}
\hline \multicolumn{2}{|l|}{ TERRITORIAL SEAS } \\
\hline $\begin{array}{l}\text { Breadth } \\
\text { (art. 3) }\end{array}$ & $\begin{array}{l}\text { Every State has the right to establish the breadth of its } \\
\text { territorial sea up to a limit not exceeding 12 nautical } \\
\text { miles, measured from baselines determined in accord- } \\
\text { ance with this Convention. }\end{array}$ \\
\hline $\begin{array}{l}\text { Legal } \\
\text { status } \\
\text { (art. 2) }\end{array}$ & $\begin{array}{l}\text { The sovereignty of a coastal State extends beyond its } \\
\text { land territory and internal waters, and in the case of an } \\
\text { archipelagic State, its archipelagic waters, to an adjacent } \\
\text { belt of sea, is described as the territorial sea. } \\
\text { This sovereignty extends to the air space over the territo- } \\
\text { rial sea, as well as to its bed and subsoil. } \\
\text { The sovereignty over territorial sea is exercised subject to } \\
\text { this Convention and to other rules of international law. }\end{array}$ \\
\hline CoNTIGUOUS zonE \\
\hline $\begin{array}{l}\text { Breadth } \\
\text { (art. 33) }\end{array}$ & $\begin{array}{l}\text { The contiguous zone may not extend beyond 24 nautical } \\
\text { miles from the baselines from which the breadth of the } \\
\text { territorial sea is measured. }\end{array}$ \\
\hline $\begin{array}{l}\text { Legal } \\
\text { status } \\
\text { (art. 33) }\end{array}$ & $\begin{array}{l}\text { In a zone contiguous to its territorial sea, described as } \\
\text { the contiguous zone, the coastal State may exercise the } \\
\text { control necessary to: } \\
\text { (a) prevent infringement of its customs, fiscal, immigra- } \\
\text { tion or sanitary laws and regulations within its territory } \\
\text { or territorial sea; } \\
\text { (b) punish infringement of the above laws and regula- } \\
\text { tions committed within its territory or territorial sea. }\end{array}$ \\
\hline
\end{tabular}




\section{EXCLUSIVE ECONOMIC ZONE \\ Breadth $\quad$ The EEZ is an area beyond and adjacent to the territorial sea. The EEZ shall not extend beyond 200 nautical miles 57) from the baselines from which the breadth of the territo- rial sea is measured. \\ In the exclusive economic zone, the coastal State has: (a) sovereign rights for the purpose of exploring and ex- ploiting, conserving and managing the natural resources, whether living or non-living, of the waters superjacent to the seabed and of the seabed and its subsoil, and with regard to other activities for the economic exploitation and exploration of the zone, such as the production of energy from the water, currents and winds; \\ Rights \\ and juris- \\ dictions \\ (art. 56) \\ of this Convention with regard to: \\ (i) the establishment and use of artificial islands, installa- tions and structures; \\ (ii) marine scientific research; \\ (iii) the protection and preservation of the marine environment; \\ (c) other rights and duties provided for in this Conven- tion.}

\section{CONTINENTAL SHELF}

\begin{tabular}{|c|c|}
\hline $\begin{array}{l}\text { Definition } \\
\text { - breadth } \\
\text { (art. 76) }\end{array}$ & $\begin{array}{l}\text { The continental shelf of a coastal State comprises the } \\
\text { seabed and subsoil of the submarine areas that extend } \\
\text { beyond its territorial sea throughout the natural prolon- } \\
\text { gation of its land territory to the outer edge of the conti- } \\
\text { nental margin, or to a distance of } 200 \text { nautical miles from } \\
\text { the baselines from which the breadth of the territorial } \\
\text { sea is measured where the outer edge of the continental } \\
\text { margin does not extend up to that distance. }\end{array}$ \\
\hline $\begin{array}{l}\text { Rights } \\
\text { (art. 77) }\end{array}$ & $\begin{array}{l}\text { The coastal State exercises sovereign rights over the } \\
\text { continental shelf for the purpose of exploring it and } \\
\text { exploiting its natural resources. } \\
\text { The natural resources referred to in this Part consist } \\
\text { of the mineral and other non-living resources of the } \\
\text { seabed and subsoil, together with living organisms } \\
\text { belonging to sedentary species, that is to say, organisms } \\
\text { which, at the harvestable stage, either are immobile } \\
\text { on or under the seabed or are unable to move except } \\
\text { in constant physical contact with the seabed or the } \\
\text { subsoil. } \\
\text { Article } 60 \text { applies mutatis mutandis to artificial islands, } \\
\text { installations and structures on the continental shelf. }\end{array}$ \\
\hline
\end{tabular}

Source: UNCLOS Convention (processed by the authors)

\section{Competencies and the public status of the sea}

Property status within T.W. is quite different in the sea from on land. On land, property status varies considerably among private, public properties and so on. For most coastal countries, however, private properties do not exist in marine space (Beriatos 2016). The public status of the sea also calls for different considerations regarding marine spatial planning and stakeholders' participation, including maritime regimes (Kraan et al. 2014; Flannery et al. 2015) and limiting the (private) interest of the citizens.

At the same time, despite being public property, competencies within the territorial waters are usually a matter of public administration (Ministries, government bodies, etc.), instead of being shared with local administration (of all tiers). This fact comes usually as a result of the lack of defined administrative (sub-national) limits in the sea. In fact, in most coastal countries, administrative boundaries are defined only on land, i.e. they extend up to the coastline and not up to the outer marine borders of a country. As a result, competencies are rarely decentralized, keeping decision making regarding the use and protection of the sea at a central/governmental level.

Considering the above, if effective Marine Spatial Planning and marine governance is to be achieved, it is important that coastal countries proceed to define their sub-national (administrative) borders within the sea, so that competencies are decentralized and decision making for the management of seas is shared between all tiers of administration.

\section{Sea, the "Terra Incognita": discussing the availability of marine and MSP data}

Despite the extensive coverage of planet earth by water, oceans and seas are still considered to be "terra incognita". Indeed, availability of data for the sea is extremely limited, compared to that for land. The missing information (PAP/RAC and University of Thessaly 2015) is usually:

- geophysical data: bathymetric/terrain data, geological faults, sea streams, currents, tides, ripples, whirlpools, wind power, etc.

- ecosystem data: Posidonia oceanica meadows, coral reefs, etc.

- resource data: fish breeding areas, fossils, minerals, oil resources, etc.

Currently there is also missing information on the socio-economic and socio-cultural data for MSP, given that the latter is mostly an place-based policy (Ehler 2017; Kyvelou 2017; MSP data study 2017).

Beyond what is lacking however, existing data also fall into several restrictions. In fact, existing data are usually available at different resolutions and digital analyses, different formats (hardcopy maps, digital maps, etc.), different coordinate systems, or even different time-scales and they are not always free (Papageorgiou 2017).

The fact that existing data for marine space is limited and that available information is likely to be incompatible creates uncertainty when planning and making decisions regarding the sea. Collection of all the necessary data is very important before implementing MSPs. Therefore, coastal countries should proceed with the creation of the appropriate databases (with longer or shorter time-series, with broader or no geographical coverage), so that critical information is gathered and is accessible to planners as well as the competent authorities responsible for MSP decision making (Flannery et al. 2015). At the same time, given the transboundary nature of the sea, it is important that geo-spatial data are aligned and harmonized between countries sharing the same seas, in order to facilitate transboundary considerations and planning initiatives. In the EU this harmonization is in progress, after the adoption of the INSPIRE Directive. 


\section{Concluding remarks: the emerging need for a transboundary approach}

Marine space constitutes a fragile ecosystem currently receiving tremendous pressure and facing many challenges and threats, due to growing competition for the marine resources and for the use of the marine space. Given these challenges, spatial planning models and techniques, which were traditionally terrestrial, become a "sine qua non" also for the marine environment. However, not all methodologies, concepts and philosophy from terrestrial spatial planning can be automatically "transplanted" to marine space.

Based on the analysis presented in the previous sections, the transboundary nature of the sea calls for special considerations in terms of planning and governance. In fact, the key particularities and differentiations to be considered in marine spatial planning and governance are:

i) The property status of seas, which is mainly under public authorities (at least within territorial waters of each coastal State). This creates a totally new spectrum of stakeholders to be involved in governance procedures, including maritime regimes, marine professionals and excluding citizens as individuals, given the fact they have no direct (private) interest in the sea.

ii) The legal aspects and jurisdictions related to the sea, that are not separately administered by each coastal state but by UNCLOS (especially beyond territorial waters). This limits sovereign rights and poses specific restrictions in the way each state may benefit from its surrounding seas.

iii) The constraints in proclaiming the EEZ (as a result of geopolitical conflicts and the partial implementation of UNCLOS). This reduces the vital area within which each coastal country can practice MSP, as well as the extent to which a coastal state may take advantage of the marine resources, economic opportunities and ecosystem services of their surrounding seas.

iv) The usually non-defined sub-national (administrative) limits in the marine parts of a coastal country that impede decentralization of decision making and of competencies related to the sea.

v) The lack of geospatial, socio-economic and socio-cultural data, confirming that both the sea and the marine geographical context are still, to a great extent, "terra incognita". This fact calls for special consideration, or even extrapolation, when spatial planning in the sea and, with respect to governance, creates uncertainty regarding the decisions to be taken by planners and by competent authorities and the stakeholders involved.

To conclude, implementing spatial planning and practicing governance in marine environments cannot just rely on experience acquired from the land. Instead, they have to be considered thoroughly and independently, having always in mind the peculiarities of the marine space (compared to the land), due to the special condi- tions and the transboundary nature of the sea. This means that when planning and governing the sea, cross-border cooperation among countries sharing the same seas is a "sine qua non", as is the need to make transboundary MSP considerations, at least at the macro-regional and sea basin scale. The adoption of tailor-made reflexive MSP arrangements also has to be further subjected to more analytical research, mainly at the sea-basin level. These conclusions are fully consistent with the already declared political interest in Transboundary MSP (2nd Forum on MSP, Paris 2017) on behalf of supra-national organisations like the EC (DGMARE) and IOC UNESCO. This interest is mostly based on the 2014 MSP directive that aims not only to support a more efficient sustainable development of marine and coastal resources, but also strengthen cross-border cooperation and therefore improve ocean/marine governance (EC, EASME 2017). The time has come to translate the policy recommendations into tailor-made practical planning and governance methods and arrangements.

\section{REFERENCES}

Beriatos E (2013) Maritime and Coastal spatial Planning: Greece in Mediterranean and Southern Europe. In: A Centenary of Spatial planning in Europe. ECTP-CEU / Editions OUTRE TERRE, Brussels, pp 31-41.

Beriatos E (2016) Between land and sea: a critical approach to the costal and maritime spatial planning. In: Kyvelou S (ed) Maritime spatial issues: maritime dimension of territorial cohesion, maritime spatial planning, sustainable blue growth. Athens, Kritiki Editions, pp 64-76 (in Greek).

CEMAT-YPEN (2015) A handbook for territorial democracy and planning participation in spatial planning. CEMAT - Hellenic Ministry for the Environment (Greek Presidency of CEMAT).

Coccossis H, Beriatos E (2016) Spatial development and planning, marine spatial planning and integrated coastal zone management. Aeichoros - Special Issue on MSP 23: 4-11 (in Greek).

Crowder LB, Osherenko G, Young OR, Airamé S, Norse EA, Baron N, Day JC, Douvere F, Ehler CN, Halpern BS, Langdon SJ, McLeod KL, Ogden JC, Peach RE, Rosenberg AA, Wilson JA (2006) Resolving mismatches in U.S. ocean governance. Science 313: 617-618.

Douvere F (2008) The importance of Marine Spatial Planning in advancing ecosystem-based sea use management. Mar Policy 32: $762-771$

Ehler Ch. (2017) "World-wide Status and Trends of Maritime/Marine Spatial Planning" presented at the 2nd International Conference on Marine/Maritime Spatial Planning, UNESCO, Paris.

Ehler Ch, Douvere F (2009) Marine Spatial Planning: a step by step approach toward ecosystem-based management. Intergovernmental Oceanographic Commission and Man and the Biosphere Programme, IOC Manual and Guides No. 53, ICAm Dossier No. 6, Paris UNESCO.

Faludi A (2012) Multi-level (Territorial) governance: Three criticisms. Planning Theory and Practice 13: 197-211.

Fernandes M, Sousa P, Lillebø A, Alves F (2013) Establishing of a guidance framework for cross-border Maritime Spatial Planning. Proceedings of the TWAM2013 International Conference and Workshops. 
Flannery W, O’Hagan A. M, O’Mahony C, Ritchie H, Twomey S (2015) Evaluating conditions for transboundary Marine Spatial Planning: Challenges and opportunities on the island of Ireland. Mar Policy 51: 86-95.

Foley M., Halpern B, Micheli F, Armsby M, Caldwell M, Crain C, Prahler E, Rohr N, Sivas D, Beck M, Carr M, Crowder L, Duffy JE, Hacker S, McLeod K, Palumbi St, Peterson C, Regan H, Ruckelshausm M, Sandifer P, Steneck R (2010) Guiding ecological principles for marine spatial planning. Mar Policy 34: 955-966.

Gilliland P, Laffoley D (2008) Key elements and steps in the process of developing ecosystem-based marine spatial planning. Mar Policy 32: 787-796.

Hall M (2001) Trends in ocean and coastal tourism: the end of the last frontier? Ocean Coast Manage 44: 601-618.

Hammer M (2015) The Ecosystem Management Approach: Implications for Marine Governance. In: Gilek M, Kern K (eds) Governing Europe's Marine Environment: Europeanization of Regional Seas Or Regionalization of EU Policies? Ashgate, Surrey, England, pp 75-92.

ICES Advisory Committee on Ecosystems (2003) Report of the Regional Ecosystem Study Group for the North Sea.

Jay S, Alves F L, O'Mahony C, Gomez M, Rooney A, Almodovar M, Kira G, Suárez de Vivero JL, Gonçalves JMS, Fernandes MdL, Tello O, Twomey S, Prado In, Fonseca C, Bentes L, Henriques G, Campos Al (2016) Transboundary dimensions of marine spatial planning: Fostering inter-jurisdictional relations and governance. Mar Policy 65: 85-96.

Kidd S, Ellis G (2012) From the Land to Sea and Back Again? Using Terrestrial Planning to Understand the Process of Marine Spatial Planning. J Environ Pol Plan 14: 49-66.

Kohler-Koch B (1999) The evolution and transformation of European governance. In: Eising R, Kohler-Koch B (eds) The Transformation of Governance in the European Union, London: Routledge, pp 14-35.

Kraan M, Hendriksen A, Van Hoof L, Van Leeuwen J, Jouanneau C (2014) How to dance? The tango of stakeholder involvement in marine governance research. Mar Policy 50: 347-352.

Kyvelou S (2016) Maritime spatial planning in the light of geophilosophy, geography and geopolitics: In: Kyvelou S (ed) Maritime spatial issues: maritime dimension of territorial cohesion, maritime spatial planning, sustainable blue growth. Athens, Kritiki Editions, pp 37-62 (in Greek).

Kyvelou S (2017) Maritime Spatial Planning as Evolving Policy in Europe: Attitudes, Challenges and Trends. EQPAM 6: 1-14.

Kyvelou S, Pothitaki I (2017) Current attitudes and lessons learnt in Maritime/Marine Spatial Planning. In: Kitsiou D, Karydis M (eds) Marine Spatial Planning. Nova Science Publishers, Inc, pp 71-92.

Lalenis K (1993) Public Participation Strategies in Urban Planning in Greece after the Urban Reconstruction Operation - 19821984. Comparison of Theory and Practice. Ph.D. Thesis, University of Westminster, UK.

Lidström A (2007) Territorial Governance in Transition. RFS 17: 499-508.

Loughlin J (2007) Reconfiguring the state: Trends in territorial governance in European states. RFS 17: 385-403.

Maes F (2008) The international legal framework for marine spatial planning. Mar Policy 32: 797-810.

MEA (2005) Millennium ecosystem assessment. Ecosystem and humans' well-being: synthesis. Washington DC: Island Press.

MSP data study - Evaluation of data and knowledge gaps to implement Maritime Spatial Planning (MSP), European Commission, 24/04/2017.

Orams M (1999) Marine Tourism: development, impacts and management. Routledge, London and New York.

PAP/RAC, University of Thessaly (2015) Paving the road towards Marine Spatial Planning in the Mediterranean, UNEP/MAP - PAP/RAC: Split. http://www.pap-thecoastcentre.org/pdfs /MSP\%20Med\%20Final\%20Report.pdf

Papageorgiou M (2016) Marine Spatial Planning and Sea-Uses: conceptual and theoretical approaches. Aeichoros 23: 41-63 (in Greek).

Papageorgiou M (2017) Aspects of spatial planning and governance in marine environments. Proceedings of the $15^{\text {th }}$ International Conference on Environmental Science and Technology, organized by Global Network on Environmental Science and Technology, Rhodes, Greece.

Raakjaer J, Leeuwen J, Van Tatenhove J, Van Hadjimichael M, (2014) Ecosystem-based marine management in European regional seas calls for nested governance structures and coordination - a policy brief. Mar Policy 50: 373-381.

Rhodes RAW (Ed) (2000) Transforming British Government. Macmillan, London.

Sassen S (2009) Bordering Capabilities Versus Borders: Implications for National Borders. 30 Mich. J. Int'l L. 567. Available at: http://repository.law.umich.edu/mjil/vol30/iss3/2

Smith H, Maes F, Stojanovic T, Ballinger R (2011) The integration of land and marine spatial planning. J Coast Conserv 15: 291-303.

Van Tatenhove JPM (2011) Integrated marine governance: questions of legitimacy. MAST 10: 87-113.

Van Tatenhove JPM (2017) Transboundary marine spatial planning: a reflexive marine governance experiment? J Environ Pol Plan, doi: 10.1080/1523908X.2017.1292120. 